\title{
A NEW FOSSIL SNAKE-FLY SPECIES \\ FROM BALTIC AMBER \\ (RAPHIDIOPTERA: INOCELLIIDAE)
}

\author{
By Michael S. ENGEL \\ Department of Entomology, \\ Comstock Hall, Cornell University, \\ Ithaca, NY 14853
}

\begin{abstract}
A new species of inocelliid snake-fly, Fibla carpenteri, is described and figured from Middle to Upper Eocene Baltic amber. The species belongs to the nominate subgenus and is the largest amber snake-fly currently known. The aberrant fossil species Inocellia peculiaris is transferred to a new genus, Electrinocellia, and placed in a new subfamily, the Electrinocelliinae, sister to the remainder of the Inocelliidae.

\section{INTRODUCTION}

Snake-flies (order Raphidioptera) are diverse in the fossil record before the Caenozoic. While only two families are recognized today, several are known from the Mesozoic and Paleozoic eras (Carpenter, 1992). Snake-flies in the Tertiary, however, are uncommon and restricted to the two living families - the Raphidiidae and the Inocelliidae. Species of the order are rare as amber inclusions. Previously, only three species have been recognized from amber (Carpenter, 1956), all in Baltic amber which is Middle to Upper Eocene in age (Kosmowska-Ceranowicz and Müller, 1985; Kosmowska-Ceranowicz, 1987). Some raphidiopteran larvae have been reported from Baltic amber inclusions (Navás, 1918; Weidner, 1958), but none have been formally described. Recent reviews of the fossil Raphidioptera have been presented by Oswald (1990); Aspöck, Aspöck, and Rausch (1991); and Carpenter (1992) with additional taxa being added by Martins-Neto and Vulcano (1990), Martins-Neto and Nel (1992), Hong (1992), and Willmann (1994).
\end{abstract}

Manuscript received 9 February 1996. 
During a recent visit to inspect and help curate the Harvard University, Museum of Comparative Zoology's fossil insect collection I happened across a remarkable new species of inocelliid snake-fly beautifully preserved in Baltic amber. This species belongs to the extant genus Fibla and is described herein. Likewise, an attempt to place the enigmatic fossil snake-fly Inocellia peculiaris Carpenter has resulted in the recognition of a new genus and subfamily sister to the remainder of the Inocelliidae. All measurements were made with an ocular micrometer on a WILD-M5a microscope.

\section{Systematic Paleontology \\ Genus Fibla Navás \\ Fibla (Fibla) carpenteri, new species}

(Figs. 1-3)

Description. Female (male and immatures unknown). Total body length (excluding ovipositor and antennae) $18.08 \mathrm{~mm}$. Head length $3.44 \mathrm{~mm}$; slightly broader posteriorly than anteriorly (Figure 1); anterior width $1.6 \mathrm{~mm}$; posterior width $2 \mathrm{~mm}$; coarsely granular, laterally weakly rugose; coronal suture strongly impressed on posterior half of head (Figure 1), anterior quarter of suture and frontal sutures very weak; head apparently dark brown to black, without pale or yellow markings. Antennae filiform, setae on antennae shorter than the length of an individual antennomere and scattered over surface. Labrum about twice as wide as long, angles rounded. Segments of labial palp becoming progressively longer distally, distal segment twice as long as first. Galea membranous; distal segment of maxillary palp longest, roughly twice as long as first, only slightly longer than second and third. Prothorax relatively short, pronotal length $2.64 \mathrm{~mm}$; width $2.16 \mathrm{~mm}$; surface granular; dark brown to black without markings. Meso- and metathorax more finely granular than prothorax; seemingly colored as on prothorax. Legs slender. Wings hyaline; forewing, however, seemingly lightly fuscous at base; veins and pterostigma brown. Left forewing length $15.52 \mathrm{~mm}$; width $5.04 \mathrm{~mm}$; costal area broad, with 9 crossveins; pterostigma 4.5 times longer than wide; MP with four medial cells; details presented in Figure 2. Left hindwing length $14.08 \mathrm{~mm}$; arculus at an oblique angle to MP; mp-ma distinct and joining MA just beyond separation of MA from $\mathrm{R}$; $\mathrm{MP}_{3+4}$ bifur- 

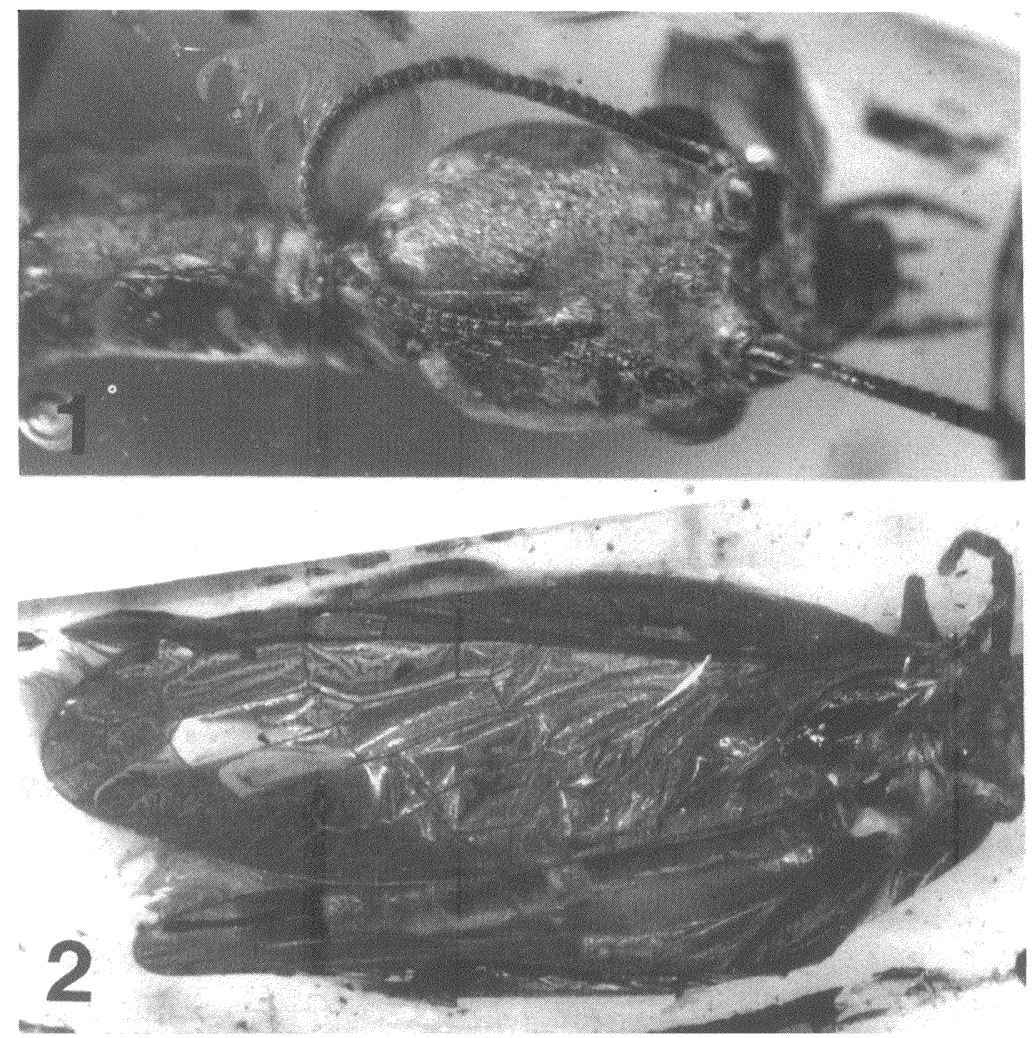

Figs. 1-2. Fibla (Fibla) carpenteri, new species. 1. Dorsal aspect of head. 2. Dorsal aspect of body showing details of left forewing.

cated; pterostigma 6 times longer than wide, as long as adjoining radial cell; details presented in Figure 3. Terga and sterna finely imbricate; seemingly dark brown, no pale or yellow markings.

Preservation. The specimen is fairly well preserved with little damage. The right forewing is torn and the distal portion missing, the antennae are incomplete, and the ovipositor is severed with the apical end lost. There is a bit of "Schimmel" (a white mold) on the right anterolateral corner of the mesothorax, base of the right forewing, at the juncture of the meso- and metathorax, under the base of the left forewing, at the base of the right hindwing, and on the right lateral surface of the meso- and metathorax. 


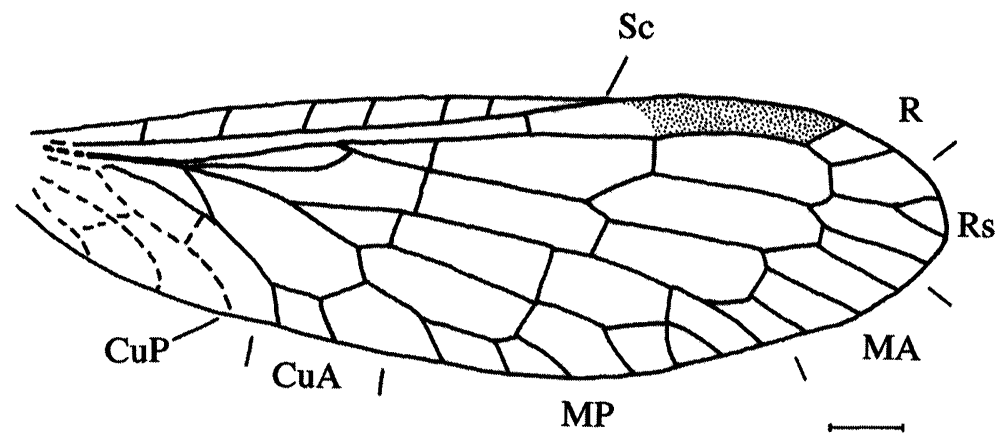

Fig. 3. Hindwing of Fibla (Fibla) carpenteri, new species. Dashed lines indicate those veins which are mostly obscured by the forewing. Scale bar $=1 \mathrm{~mm}$.

Type Material. Holotype female, Eocene Baltic amber, deposited in the Museum of Comparative Zoology, accession number 9999.

Etymology. This species is named in honor of the late Dr. Frank M. Carpenter (1902 - 1994), world's authority on fossil insects. Dr. Carpenter had a particular interest in the Raphidioptera (both recent and fossil) and it is only fitting that one should bear his name.

Remarks. Of the known amber Raphidioptera this is the largest species with its forewing length of $15.52 \mathrm{~mm}$. Additionally, $F$. carpenteri is slightly larger than any of the extant species in the genus, the next largest species being $F$. pasiphae with a female forewing length of up to $15.5 \mathrm{~mm}$. This species, however, belongs to the monotypic subgenus Reisserella distinguished by the presence of five medial cells beyond MP in the forewing.

One of the three previously described amber Raphidioptera also belongs to the genus Fibla. F. erigena was described by Hagen (1854) as Raphidia (Inocellia) erigena and was redescribed by Carpenter (1956). Carpenter's description was based on two specimens, neither of which was the type (Carpenter presumed the type to be lost). The species described herein is much larger than F. erigena which has a forewing length of $10-13 \mathrm{~mm}$ and a hindwing length one-third that of $F$. carpenteri. Only one other fossil species of Fibla is known at this time. F. exusta is from the EoceneOligocene boundary of Florissant, Colorado (Cockerell and Custer, 1925: as Inocellia exusta). 


\section{Placement of Inocellia peculiaris Carpenter}

(Orig. Comb.)

Electrinocelliinae, new subfamily

(Type genus: Electrinocellia, new genus)

Diagnosis. Typical characters as for the family Inocelliidae, absence of ocelli and pterostigmal vein, with the modifications indicated below. Overall size small. Head not as strongly quadrate as in the remainder of the Inocelliidae, seemingly intermediate between the tapered heads of Raphidiidae and the more strongly quadrate heads of the Inocelliinae. Costal area of forewing narrow. Hindwing with arculus orthogonal to MP, reminiscent of some Raphidiidae; MP with two medial cells (Figure 4); $\mathrm{MP}_{3+4}$ not bifurcated as in the remainder of inocelliid genera, structure like that in Raphidiidae; details of hindwing presented in Figure 4. Head and wing venation also figured by Carpenter (1956: his figure 3).

Remarks. Based on the characters mentioned above this species clearly falls outside all of the currently known genera of Inocelliidae. Electrinocelliinae has several characteristics reminiscent of Raphidiidae, but clearly falls within Inocelliidae due to the absence of ocelli and a pterostigmal vein. The remaining genera of the Inocelliidae (here relegated to a nominate subfamily, the

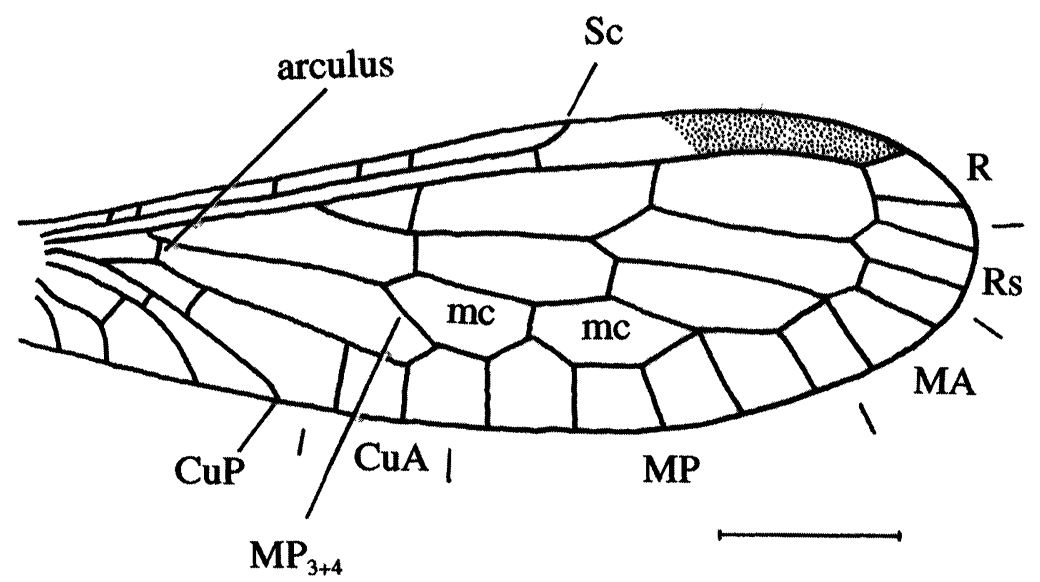

Fig. 4. Hindwing of Electrinocellia peculiaris (Carpenter); mc, medial cell. Redrawn from Carpenter (1956). Scale bar $=1 \mathrm{~mm}$. 
Inocelliinae, containing the genera-Fibla, Indianoinocellia, Inocellia, Negha, Parainocellia, and Sininocellia) share the bifurcation of $\mathrm{MP}_{3+4}$, the oblique m-cu crossvein, and the strongly quadrate heads. The internal phylogeny of the Inocelliinae has been discussed by Aspöck et al. (1991: as the Inocelliidae).

Electrinocellia, new genus

(Type species: Inocellia peculiaris Carpenter, 1956)

Diagnosis. As for the subfamily.

Etymology. The generic name is a combination of electr- (L. electrum = amber) and Inocellia , type genus of the Inocelliidae.

Remarks. Carpenter (1956) originally noted the enigmatic nature of this species (hence the name peculiaris); however, he went ahead and grudgingly placed it in the genus Inocellia. Aspöck et al. (1991) also noted the dubious position of this taxon but made no further attempt to place the species within the Inocelliidae.

Included species. Electrinocellia peculiaris (Carpenter), new combination. Type located in the Museum of Comparative Zoology, accession number 5123 .

\section{ACKNOWLEDGMENTS}

Special thanks are due to G. Chavarría, S. Cover, and P. Perkins for cordially helping me during my visits to the Museum of Comparative Zoology. I am grateful to J. Kukalova-Peck who offered comments on the manuscript and valuable discussion of neuropteroid wing venation. Her efforts helped to improve the final version. I am additionally indebted to J.K. Liebherr for providing access to a camera-microscope setup used in preparing Figures 1 and 2. Support for this work was provided by a National Science Foundation Predoctoral Fellowship.

\section{Literature Cited}

Aspöck, H., U. Aspöck, and H. Rausch. 1991. Die Raphidiopteren der Erde, I und II. Goecke und Evers, Krefeld, Germany. (I) 730 p. (II) 550 p.

Carpenter, F.M. 1956. The Baltic amber snake-flies (Neuroptera). Psyche 63:77-81. Carpenter, F.M. 1992. Treatise on Invertebrate Paleontology, Part R, Arthropoda 4. (Ed. R.L. Kaesler), Geological Society of America, Boulder, CO.

Cockerell, T.D.A., and C. Custer. 1925. A new fossil Inocellia (Neuroptera) from Florissant. Entomologist 58:295-297. 
Hagen, H. 1854. Über die Neuropteren der Bernsteinfauna. Verh. zool. -bot. Ver., Wien 4:221-232.

Hong, Y.C. 1992. A new family of Mesozoic snake-flies (Insecta, Raphidioptera) from the Laiyang Basin, China. Paleontol. Zh. 1992:101-105. [In Russian]

Kosmowska-Ceranowicz, B. 1987. Mineralogical-petrographic characteristics of the Eocene amber-bearing sediments in the area of Chlapowo, and the Palaeogene sediments of Northern Poland. Biuletyn Inst. Geolog. 356:29-50.

Kosmowska-Ceranowicz, B., and C. Müller. 1985. Lithology and calcareous nannoplankton in amber bearing Tertiary sediments from boreholes, Chlapowo (Northern Poland). Bull. Polish Acad. Sci. 33:119-129.

Martins-Neto, R.G., and M.A. Vulcano. 1990. Primeiro registro de Raphidioptera (Neuropteroidea) na Formação Santana (Cretáceo Inferior), Bacia do Araripe, nordeste do Brasil. Revta. bras. Entomol. 34:241-249.

Martins-Neto, R.G., and A. Nel. 1992. Un nouveau fossile de Raphidioptère de la Formation Santana, Crétacé inférieur du Brésil (Neuropteroidea, Raphidioptera). Bull. Soc. ent. France 97:425-428.

Navás, L. 1918. Monografia de l’ordre dels Rafidiópters (Ins.). Publ. Inst. Ci. Barcelona 1918:1-90.

Oswald, J.D. 1990. Raphidioptera. P. 154-163 In: Insects from the Santana Formation, Lower Cretaceous, of Brazil. (Ed. D.A. Grimaldi). Bull. Amer. Mus. Nat. Hist. 195:1-191.

Weidner, H. 1958. Einige interessante Insektenlarven aus der BernsteininklusenSammlung des geologischen Staatsinstituts Hamburg (Odonata, Coleoptera, Megaloptera, Planipennia). Mitt. geol. StInst. Hamburg 27:50-68.

Willmann, R. 1994. Raphidiodea aus dem Lias und die Phylogenie der Kamelhalsfliegen (Insecta: Holometabola). Palaeont. Zeitschr. 68:167-197. 

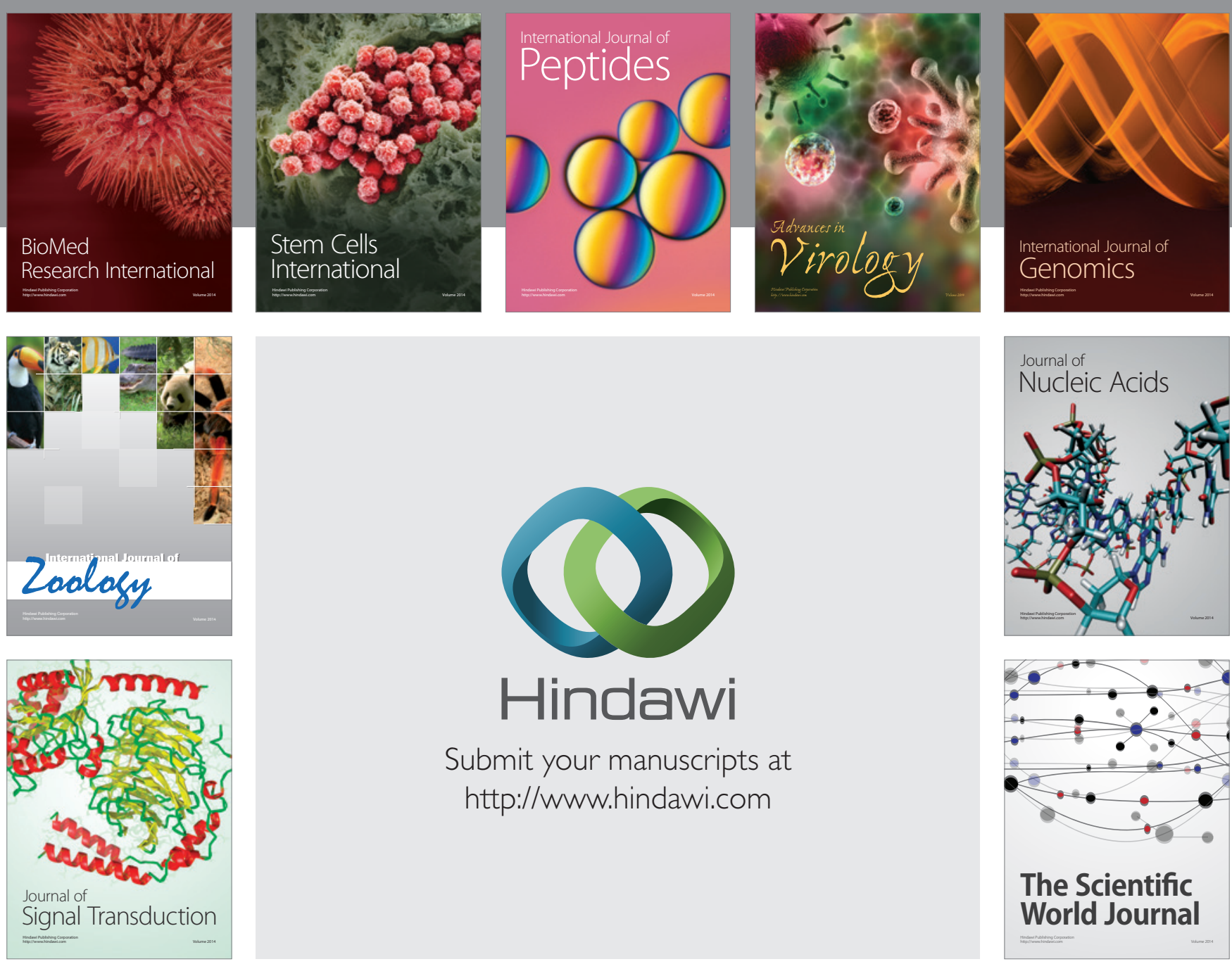

Submit your manuscripts at

http://www.hindawi.com
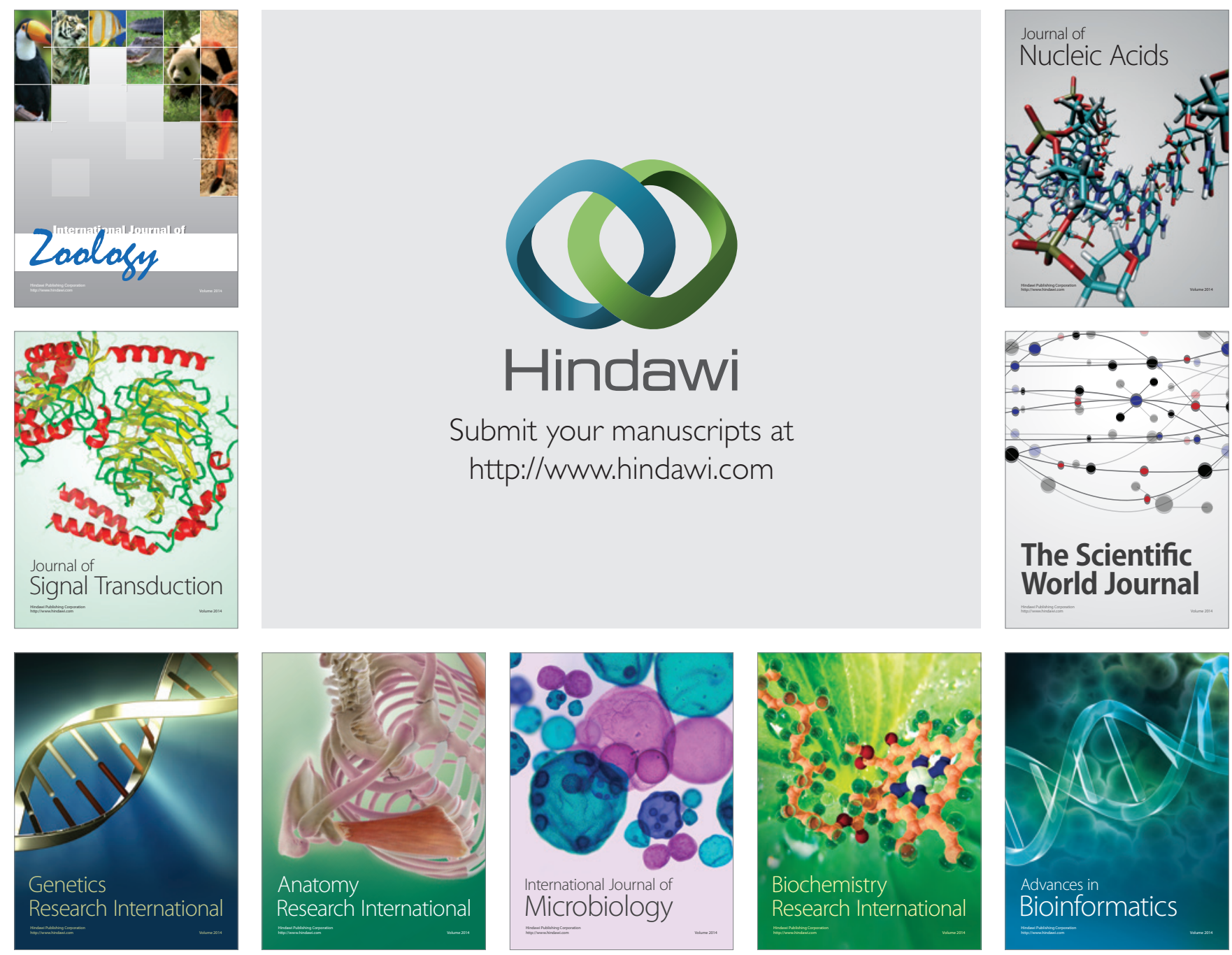

The Scientific World Journal
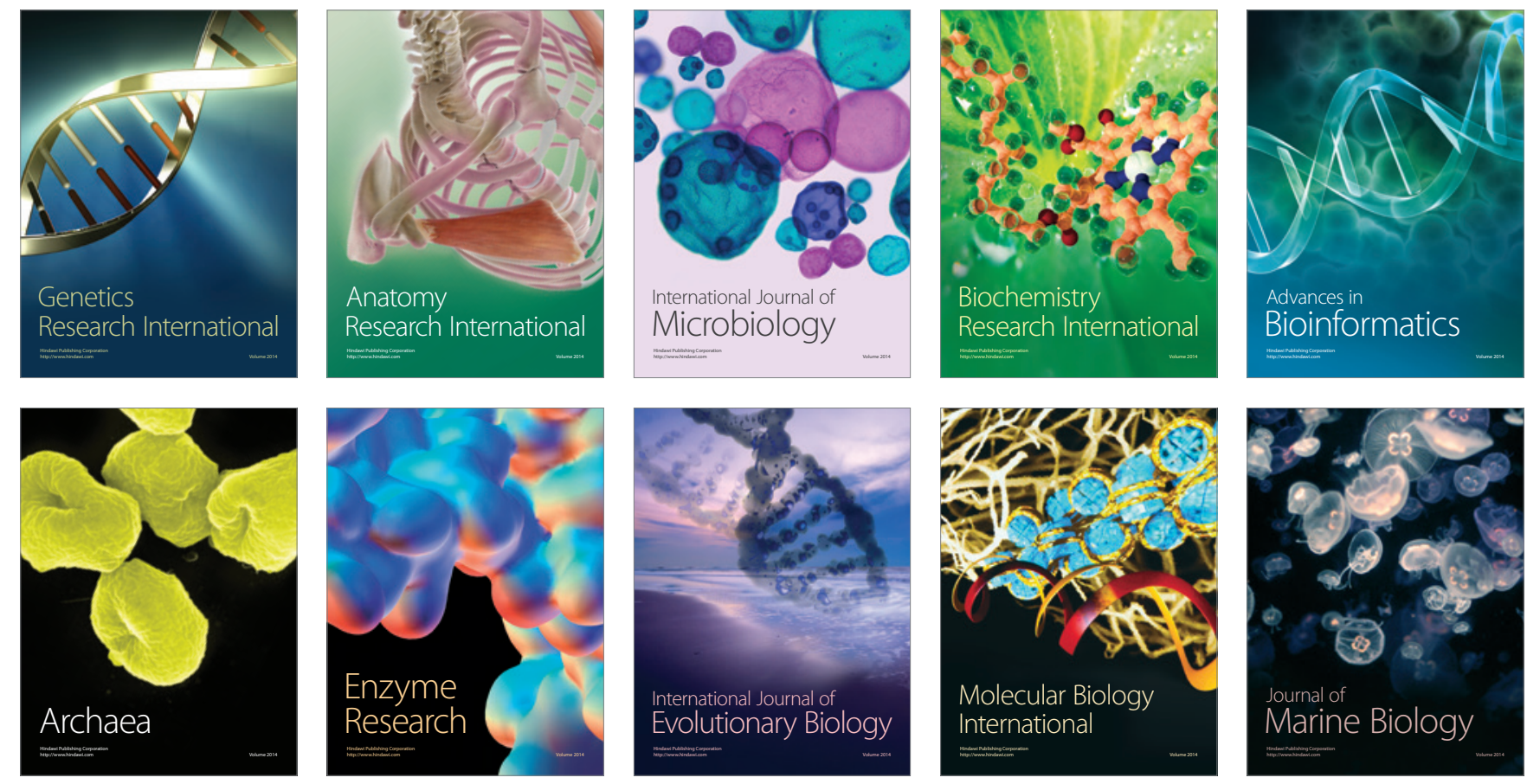